\author{
ACTA MYCOLOGICA \\ Vol. 43 (1): 5-12 \\ 2008
}

\title{
Cristulariella depraedans as causal agent of leaf spots of a maple and other trees and shrubs
}

\author{
TADEUSZ KOWALSKI and CZESŁAW BARTNIK
}

\begin{abstract}
Department of Forest Pathology, University of Agriculture in Kraków
Al. 29. Listopada 46, PL-31-425 Kraków, rltkowal@cyf-kr.edu.pl
\end{abstract}

Kowalski T., Bartnik Cz.: Cristulariella depraedans as causal agent of leaf spots of maple and other trees and shrubs. Acta Mycol. 43 (1): 5-12, 2008.

Results of the first studies in Poland on Cristulariella depraedans, the causal agent of necroses on tree and shrub leaves, are presented. The fungus was recorded on Acer platanoides, A. pseudoplatanus and eight other species of trees and shrubs, including Corylus avellana, Fagus sylvatica, Lonicera xylosteum and Padus avium that were not previously known as hosts of the fungus. The disease symptoms, which depend on the host plant species, the size and number of necrotic lesions on leaves, and the morphological features of the fungal propagules were characterized.

Key words: Cristulariella depraedans, Acer spp., leaf spots, host range

\section{INTRODUCTION}

Many and various symptoms with abiotic and biotic causes occur on leaves of maple trees, Acer platanoides L. and A. pseudoplatanus L. Only some of them are easily recognizable.These include symptoms caused by fungi, e.g. Rhytisma acerinum (Pers.) Fr. and R. punctatum (Pers.) Fr. (Butin 1996; Mańka 2005) or by gall-forming insects and mites, e.g. Harrisomyia vitrina (Kieffer) and Eriophyes pseudoplatani Corti (Skrzypczyńska 2004). The joint action of fungi and gall-forming insects in the development of necroses can make the diagnosis of their causal agents difficult. Kowalski (2003) recorded 18 species of fungi within the necrotic areas accompanying the galls caused by Drisina glutinosa Giard. The most significant were Colletotrichum gloeosporioides (Penz.) Sacc., Diplodina acerina (Pass.) Sutton, Discula campestris (Pass.) Arx and Phomopsis platanoidis Died. Similar associations were reported by Wulf (1990), who found 12 species of fungi on leaves of $A$. pseudoplatanus within the necrotic tissues of galls caused by Dasineura vitrina Kieffer. A great variety of fungi can infect maple leaves and recognition of symptoms and signs caused by individual potential causal agents is necessary. 
Studies on diseases of forest trees in the south of Poland led to the identification of Cristulariella depraedans (Cooke) Hoehn., a fungus that occurred commonly on maple leaves in a few locations. Since the species has not been recorded in Poland previously, the objective of this study was to present an analysis of symptoms and signs of infection by the pathogen on maple tree leaves. The symptoms on leaves of the other species of trees and shrubs growing in proximity to the infected maples were also analysed to indicate the pathogen's hosts range.

\section{MATERIALS AND METHODS}

The study was carried out in 1996-2006, in four localities in the south of Poland (Tab. 1). The majority of observations were made in Ojców National Park, where the trees and shrubs along a route that included the Lokietek Cave, Ojców centre, Prądnik valley, the Kraków Gate and again the Łokietek Cave were surveyed and analysed. From July to October, 1-3 times a year, 30 to 60 leaves with different disease symptoms were collected from 30 trees, mostly self-sown, of Acer pseudoplatanus and $A$. platanoides. Samples were either from young trees or from the lower parts of the crowns of older trees. On each occasion, 3-6 diseased leaves from each of 20 other species of trees and shrubs growing in the surrounding area were also collected and assessed (Tab. 2). Their grouping according to the type of symptoms and the presence of sporulation of $C$. depraedans was made in the laboratory. The number and size of necrotic lesions caused by $C$. depraedans on 165 maple leaves collected at random from severely affected trees were evaluated. The sizes of similar lesions on leaves of the other species of trees and shrubs and the pigmentation of the necrotic tissues in the centres of the lesions and at their borders with the living leaf tissues were also determined.

The propagules formed by $C$. depraedans were examined microscopically and a macro- and microphotographic record was made of the symptoms and signs of infection by $C$. depraedans. The nomenclature of host plants is given after Mirek et al. (2002).

\section{RESULTS}

Cristulariella depraedans was recorded in four localities in the south of Poland (Tab. 1). It was common in Ojców and Tatra National Parks and Wolski Forest (Tab. 3) but occurred only sporadically in Świerklaniec Forest District. In Ojców National Park, most infection was recorded in 1996-1998, when more than $80 \%$ of trees growing along the route surveyed had local necrotic lesions caused by $C$. depraedans on their leaves. In a few young maple trees, up to $1 \mathrm{~m}$ high, all leaves in the crowns were infected (Fig. 1).

In Tatra National Park, Świerklaniec Forest District and Wolski Forest, C. depraedans occurred only on leaves of $A$. pseudoplatanus, and in Ojców National Forest it occurred on both species of Acer and on eight species of other trees and shrubs, viz. Carpinus betulus, Cornus sanguinea, Corylus avellana, Fagus sylvatica, Lonicera xylosteum, Padus avium, Quercus robur and Tilia cordata. There were no symptoms of infection by $C$. depraedans on a further 12 species of trees and shrubs growing in the area surrounding the infected maples (Tab. 2). 
Table 1

Locations and periods of study and plant species examined

(E, examined; N, no symptoms and not examined)

\begin{tabular}{|c|c|c|c|c|c|}
\hline \multirow[t]{2}{*}{ Area studied } & \multirow{2}{*}{$\begin{array}{l}\text { Period of } \\
\text { studies }\end{array}$} & \multirow{2}{*}{$\begin{array}{c}\text { Number of } \\
\text { observations } \\
\text { in a year }\end{array}$} & \multicolumn{3}{|c|}{ Species of plants studied } \\
\hline & & & $\begin{array}{c}\text { Acer } \\
\text { platanoides }\end{array}$ & $\begin{array}{c}\text { Acer } \\
\text { pseudoplatanus }\end{array}$ & $\begin{array}{l}\text { Other species of } \\
\text { tress and shrubs }\end{array}$ \\
\hline Ojców National Park & $\begin{array}{l}1996-2002, \\
2006\end{array}$ & $2-3$ & $\mathrm{E}$ & $\mathrm{E}$ & $\mathrm{E}$ \\
\hline Tatra National Park & $\begin{array}{l}1999-2002, \\
2005\end{array}$ & 1 & $\mathrm{~N}$ & $\mathrm{E}$ & $\mathrm{E}$ \\
\hline $\begin{array}{l}\text { Świerklaniec Forest } \\
\text { District }\end{array}$ & $\begin{array}{c}1999-2002, \\
2006\end{array}$ & $1-2$ & $\mathrm{~N}$ & $\mathrm{E}$ & $\mathrm{E}$ \\
\hline Wolski Forest & 2001-2002 & 1 & $\mathrm{~N}$ & $\mathrm{E}$ & $\mathrm{E}$ \\
\hline
\end{tabular}

List of species is given in Table 2

Some differences were observed in the symptoms caused by $C$. depraedans on $A$. pseudoplatanus and $A$. platanoides, and on other plant species.

Up to 438 necrotic lesions per leaf, with lesion diameters up to $22 \mathrm{~mm}$, occurred on $A$. pseudoplatanus (Tabs 2,3). Single lesions were almost round, greyish-white in the centre and dark grey at the edge (Tab. 2; Figs 1, 2).

Table 2

Presence, size and appearance of lesions caused by Cristulariella depraedans on different trees and shrubs

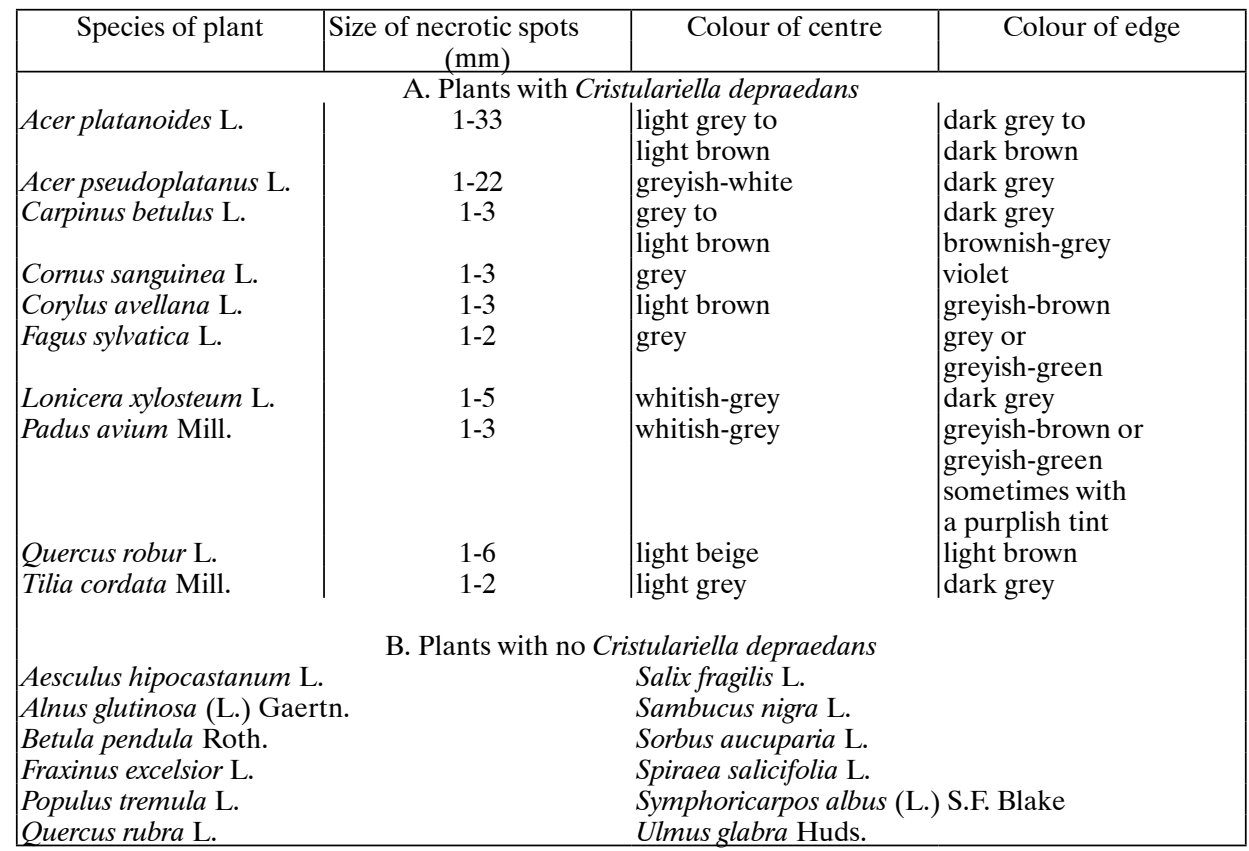


Germinating $C$. depreadans propagules were often seen within the initial and smallest lesions. Disintegration of the necrotic tissues caused irregular perforations between the leaf veins in a few of the more advanced lesions. Single, adjacent lesions sometimes merged and the severely infected leaves rolled up, died and were shed prematurely, often as early as August. Up to 338 local lesions per leaf occurred on A. platanoides (Tab. 3). Small lesions were $2-5 \mathrm{~mm}$ in diameter and larger lesions reached up to $33 \mathrm{~mm}$ in diameter (Tab. 3, Fig. 3). The lesions were light grey to light brown in the centre and dark grey to dark brown at the edge. As on leaves of $A$. pseudoplatanus, germinating propagules of $C$. depraedans were often seen within the initial and smallest lesions (Fig. 4). Lesions caused by $C$. depraedans on leaves of A. pseudoplatanus at Ojców National Park were larger than those recorded at the same time at Tatra National Park (Tab. 3).

Table 3

Numbers and size ranges of lesions caused by Cristulariella depraedans on leaves of Acer platanoides and $A$. pseudoplatanus at different periods of study

\begin{tabular}{|c|c|c|c|c|c|}
\hline \multirow[t]{2}{*}{ Studied area } & \multirow[t]{2}{*}{$\begin{array}{l}\text { Period of } \\
\text { studies }\end{array}$} & \multirow[t]{2}{*}{$\begin{array}{l}\text { Number of } \\
\text { leaves }\end{array}$} & \multicolumn{3}{|c|}{$\begin{array}{l}\text { Summary number of necroses with diam } \\
(\mathrm{mm}) \\
\text { (minimal and maximal number on a leaf) }\end{array}$} \\
\hline & & & $<5$ & $6-10$ & $>10$ \\
\hline \multicolumn{6}{|c|}{ Acer platanoides } \\
\hline Ojców National Park & VIII.1997 & 10 & $\begin{array}{c}706 \\
(2-308)\end{array}$ & $\begin{array}{c}63 \\
(2-16)\end{array}$ & $\begin{array}{c}73 \\
(2-14)\end{array}$ \\
\hline Ojców National Park & VIII.2000 & 10 & $\begin{array}{c}710 \\
(32-113)\end{array}$ & $\begin{array}{c}146 \\
(8-26)\end{array}$ & $\begin{array}{c}30 \\
(1-6)\end{array}$ \\
\hline Ojców National Park & VIII.2001 & 10 & $\begin{array}{c}340 \\
(4-91)\end{array}$ & $\begin{array}{c}52 \\
(0-11)\end{array}$ & $\begin{array}{c}46 \\
(1-9)\end{array}$ \\
\hline \multicolumn{6}{|c|}{ Acer pseudoplatanus } \\
\hline Ojców National Park & VIII.1997 & 30 & $\begin{array}{c}4435 \\
(12-373)\end{array}$ & $\begin{array}{c}122 \\
(0-25)\end{array}$ & $\begin{array}{c}11 \\
(0-6)\end{array}$ \\
\hline Ojców National Park & VIII.2000 & 30 & $\begin{array}{c}5863 \\
(18-399)\end{array}$ & $\begin{array}{c}423 \\
(1-37)\end{array}$ & $\begin{array}{c}12 \\
(0-2)\end{array}$ \\
\hline Ojców National Park & VIII.2001 & 30 & $\begin{array}{c}4501 \\
(42-321)\end{array}$ & $\begin{array}{c}172 \\
(1-14)\end{array}$ & $\begin{array}{c}14 \\
(0-3)\end{array}$ \\
\hline Tatra National Park & VIII.2000 & 15 & $\begin{array}{c}557 \\
(9-107)\end{array}$ & $\begin{array}{c}0 \\
(0-0)\end{array}$ & $\begin{array}{c}0 \\
(0-0)\end{array}$ \\
\hline Tatra National Park & VIII.2002 & 15 & $\begin{array}{c}1721 \\
(0-219)\end{array}$ & $\begin{array}{c}46 \\
(0-11)\end{array}$ & $\begin{array}{c}2 \\
(0-1)\end{array}$ \\
\hline Wolski Forest & X.2001 & 15 & $\begin{array}{c}442 \\
(3-104)\end{array}$ & $\begin{array}{c}155 \\
(429)\end{array}$ & $\begin{array}{c}57 \\
(0-8)\end{array}$ \\
\hline
\end{tabular}


Leaves of other species of plants were infected by $C$. depraedans to different extents. The largest numbers of necrotic lesions per leaf were recorded on Cornus sanguinea (up to 582) and on Quercus robur (up to 286) (Figs 7, 9). Lesions diameters were between 1 and $6 \mathrm{~mm}$ (Tab. 2). The necrotic tissues showed more or less distinctive differences in pigmentation of the central and peripheral parts in all the species of plants studied (Tab. 2). The near-violet pigmentation of the lesion edges on leaves of Cornus sanguinea and greyish-green pigmentation on leaves of Padus avium and Fagus sylvatica were the most characteristic (Tab. 2, Fig. 9). Differences in pigmentation of these tissues were not species-specific. A similar range of pigmentation was observed during these studies on leaves of $C$. sanguinea infected by Septoria cornicola Desm., of $P$. avium infected by Stigmina carpophila (Lev.) M.B. Ellis, and on a few leaves of $F$. sylvatica in the necrotic tissue surrounding galls caused by Mikiola fagi (Hartig) and inhabited by Apiognomonia errabunda (Rob.) Hoehn.

The whitish propagules of $C$. depraedans, which were clearly discernible against the greyish background of the lesions, were observed in the necrotic areas on the undersides of leaves and sometimes also on the upper surface of the leaf blades (Fig. 5). Propagules were bulb-shaped, round, slightly flatten or slightly elongated $60-140 \mu \mathrm{m}$ in diameter, mounted on a septate, hyaline stipe, $120-180 \mu \mathrm{m}$ long and $10-15 \mu \mathrm{m}$ wide (Fig. 6). The bulb, which consisted of many single, round cells, $6-9$ $\mu \mathrm{m}$ in diameter, was readily separated from the stipe.

\section{DISSCUSION}

The fungus Cristulariella depraedans has been known since the end of 19th century, when it was described as Polyactis depraedans Cooke (Cooke 1885). It is not a commonly occurring species. It has been recorded previously only in the United Kingdom, Germany, Austria and the USA (Cooke 1885; Saccardo 1908; Sydow 1912; Bowen 1930; Batko 1974; Butin 1981a; Cech, Donaubauer 1990; Wulf 1994). The present studies show that it also occurs in the south of Poland, where it was first recorded in Ojców National Park. Its occurrence in abundance was associated mainly with heavy rainfall in the growing season of 1996-1997 (Feliksik et al. 2002; Saramak 2005). The significance of wet conditions for the development of the fungus was also noticed and emphasized by Bowen (1930), Butin (1981b), Cech and Donaubauer (1990), Wulf (1994) and Lang (2000). Favorable moisture conditions can be also found on the leaves of susceptible young trees regenerated naturally and growing under the canopy of older stands. In Ojców and Tatra National Parks, favourable moisture conditions occur in the numerous depressions and valleys.

For more than 100 years the host range of $C$. depraedans has been known to include various species of Acer, Bucida buceras L. and Aruncus dioicus (Walt.) Fern. (Redhead 1975; Lang 2000). Only recently studies in Germany in 1996-1999 showed that $C$. depraedans has a much broader potential host range than known previously. Lang (2000) reported its occurrence on 21 woody and herbaceous plants other than Acer species. The present studies also confirmed that the host range of $C$. depraedans is not limited to plants within genus of Acer. In Ojców National Park, the fungus was observed on eight other species of plants growing in the areas around the infected $A$. platanoides and $A$. pseudoplatanus. Four of them, Corylus avellana, Fagus 
sylvatica, Lonicera xylosteum and Padus avium, are new additions to the host range of $C$. depraedans.

Lang (2000) showed that the size and pigmentation of necrotic lesions and their edges, next to the living leaf tissues, depend on the species of host plant and are related to differences in their susceptibility. Lesions were different in size on leaves of A. pseudoplatanus, A. platanoides and the other plant species studied. This undoubtedly resulted from the interval of time between infection and observation. It should be mentioned that propagules formed within lesions were transferred to other leaves and to other parts of the leaf that had the primary infection, and caused secondary infections at different times in the same growing season. Occasionally, germinating fungal propagules were observed on the initial necroses, with diameters not exceeding $1 \mathrm{~mm}$, in the second half of the growing season. Despite the differences in lesion sizes resulting from the period of infection, effects of host plant on the lesion dimensions were also observed. The larger lesions on leaves of $A$. platanoides seem to suggest that it is more susceptible than $A$. pseudoplatanus.

The propagules of $C$. depraedans found in Poland did not differ morphologically from those found in other countries (Redhead 1975; Willetts 1997; Butin 1981b; Wulf 1994). Their presence is essential for the identification of $C$. depraedans because the lesions are not specific and are very similar to those caused by other fungi or insects and mites causing galls (Kowalski 2003; Skrzypczyńska 2004).

The present studies confirm that, on the plants examined, there was no co-occurrence of a related species, Cristulariella moricola (Hino) Redhead (syn. C. pyramidalis Waterman \& Marshall), which has propagules that are of different shape (Redhead 1975; Trolinger et al. 1978).

Acknowledgement. The study was supported by the Ministry of Science and Higher Education, grant no. 2 P06L 03626.

\section{REFERENCES}

Batko S. 1974. Notes on new and rare fungi on forest trees in Britain. Bull. Br. Mycol. Soc. 8: 19-21.

Bowen P. R. 1930. A maple leaf disease caused by Cristulariella depraedans. Conn. Agric. Exp. Stn. Bull. 316: 625-647.

Butin H. 1981a. Aktuelle Baumkrankheiten im Forst. Mitt. Biol. Bundesanst. Land - Forstw. BerlinDahlem. 203: 177-178.

Butin H. 1981b. Die Weißfleckigkeit des Bergahorns - eine „neue“ Blattkrankheit. Allg. Forstzeitschrift. 14: 327-328.

Butin H. 1996. Krankheiten der Wald- und Parkbäume. Thieme Verlag. Stuttgart.

Cech T. L., Donaubauer E. 1990. Cristulariella depraedans - Weissfleckenkrankheit von Ahornblättern. Forstschutz Aktuell. 12: 3.

Cooke M. C. 1885. Some remarkable moulds. Jour. Quek. Micr. Club. S. II, 2: 138-143.

Feliksik E., Wilczyński S., Durło G. 2002. Charakterystyka zmienności opadów atmosferycznych na Kopciowej koło Krynicy Zdroju w latach 1971-2000. Acta Agr. et Silv., ser. Silv. 40: 5-16.

Kowalski T. 2003. Endophytic fungi: V. Mycobiota in living leaves of Acer pseudoplatanus and in necrotic tissues around galls of Drisina glutinosa. Phytopath. Pol. 29: 23-35.

Lang K. J. 2000. New hosts of Cristulariella depraedans. For. Path. 30: 117-120.

Mańka K. 2005. Fitopatologia leśna. PWRiL. Warszawa.

Mirek Z., Piękoś-Mirkowa H., Zając A., Zając M. 2002. Flowering plants and pteridophytes of Poland. A checklist. W. Szafer Institute of Botany, Polish Academy of Sciences, Kraków.

Redhead S. A. 1975. The genus Cristulariella. Can. J. Bot. 53: 700-707. 
Redhead S. A. 1979. Mycological observations: 1, on Cristulariella; 2, on Valdensenia; 3, on Neolecta. Mycologia 71: 1248-1253.

Saccardo P. A. 1908. Notae Mycologicae. Series X. Ann. Mycol. 6: 553-569.

Saramak A. 2005. Opady atmosferyczne w Gaiku-Brzezowej w latach 1971-2000. (In:) E. Bogdanowicz, U. Kossowska-Cezak, J. Szkutnicki (eds). Ekstremalne zjawiska hydrologiczne i meteorologiczne. Polskie Towarzystwo Geofizyczne IMGW, Warszawa: 184-197.

Skrzypczyńska M. 2004. Studies on the population frequency of insects and mites causing galls on the leaves of the sycamore maple Acer pseudoplatanus L. in southern Poland. J. Pest. Sci. 77: 49-51.

Sydow P. 1912. Mycotheca Germanica. Fasc. XXII-XIII. Ann. Mycol. 10: 445-451.

Trolinger J. C., Elliott E. S., Young R. J. 1978. Host range of Cristulariella pyramidalis. Plant Dis. Reporter 62: 710-714.

Willetts H. J. 1997. Morphology, development and evolution of stromata/sclerotia and macroconidia of the Sclerotiniaceae. Mycol Res. 101 (8): 939-952.

Wulf A. 1990. Über die Bedeutung von Diplodina acerina (Pass.) Sutton und anderen Blattpilzen als Antagonisten der Fenstergallmücke Dasineura vitrina Kffr. an Bergahorn (Acer pseudoplatanus L.). Nachrichtenbl. Pflanzenschutzd. 42: 97-102.

Wulf A. 1994. Pilzbedingte Blattkrankheiten an Ahorn unter besonderer Berücksichtigung des Bergahorns (Acer pseudoplatanus L.). Schriften aus der Forstlichen Fakultät der Universität Göttingen und der Niedersächsischen Forstlichen Versuchsanstalt. 116: 46-58.

\section{Cristulariella depreadens jako sprawca plamistości liści klonów oraz innych drzew i krzewów}

Streszczenie

Badania prowadzono w okresie 1996-2006 na terenie Ojcowskiego PN, Tatrzańskiego PN, Nadl. Świerklaniec i w Lesie Wolskim koło Krakowa (Tab. 1). W okresie od lipca do października, z 30 powstałych zwykle w wyniku samosiewu młodych drzew oraz dolnych partii koron drzew starszych Acer pseudoplatanus i A. platanoides pobierano 1 - 3-krotnie 30 do 60 liści wykazujących różne objawy chorobowe oraz po 3 do 6 liści z objawami chorobowymi dwudziestu innych gatunków drzew i krzewów rosnących w sąsiedztwie badanych klonów (Tab. 2). W laboratorium dokonywano analizy nekroz i oznak etiologicznych C. depraedans.

C. depraedans stwierdzony został we wszystkich czterech rejonach, gdzie pobierano materiał do badań, przy czym na terenie Nadleśnictwa Świerklaniec $C$. depraedans występował tylko sporadycznie. Na terenie Tatrzańskiego PN, Nadl. Świerklaniec i w Lesie Wolskim $C$. depraedans stwierdzono tylko na liściach Acer pseudoplatanus, natomiast w Ojcowskim PN na obu badanych gatunkach klonów oraz na 8 innych gatunkach drzew i krzewów: Carpinus betulus, Cornus sanguinea, Corylus avellana, Fagus sylvatica, Lonicera xylosteum, Padus avium, Quercus robur i Tilia cordata. Na 12 innych gatunkach drzew i krzewów rosnących w sąsiedztwie porażonych klonów nie stwierdzono objawów porażenia przez C. depraedans (Tab. 2).

Występowały pewne różnice w objawach porażenia zarówno pomiędzy $A$. pseudoplatanus i $A$. platanoides, jak i pomiędzy pozostałymi gatunkami roślin. Na jednym liściu $A$. pseudoplatanus występowało od 9 do 438 nekroz. Osiągały one do $22 \mathrm{~mm}$ średnicy (Tab. 3). Pojedyncze nekrotyczne plamy były prawie okrągłe, w części środkowej szarobiałe, w części przyobwodowej ciemnoszare (Tab. 2; Figs 1, 2). Na jednym liściu $A$. platanoides występowało do 338 lokalnych nekroz (Tab. 3). Oprócz nekroz małych 1 do $5 \mathrm{~mm}$ średnicy, obecne były nekrozy do 33 mm średnicy (Tab. 3; Fig. 3). Nekrotyczne plamy miały barwę jasnoszarą do jasnobrunatnej w części centralnej, oraz ciemnoszarą lub brunatnoszarą w strefie graniczącej z tkankami żywymi. Liście pozostałych gatunków roślin porażone były przez $C$. depraedans w różnym stopniu. Najwięcej nekrotycznych plam stwierdzono na liściach Cornus sanguinea i Quercus robur, odpowiednio do 582 i do 286 plam (Figs 7, 9). Średnica nekrotycznych plam u roślin spoza rodzaju Acer wahała się w granicach od 1 do $6 \mathrm{~mm}$ (Tab. 3). U wszystkich gatunków roślin 
nekrotyczne tkanki wykazywały mniej lub bardziej wyraźne różnice w zabarwieniu pomiędzy częścią środkową i przyobwodową (Tab. 3).

Propagule miały postać kulistej lub lekko spłaszczonej względnie nieco wydłużonej, wielokomórkowej główki o średnicy 60 do $140 \mu \mathrm{m}$ osadzonej na septowanym, hyalinowym trzonku o długości 120-180 $\mu \mathrm{m}$ i grubości 10-15 $\mu \mathrm{m}$. 

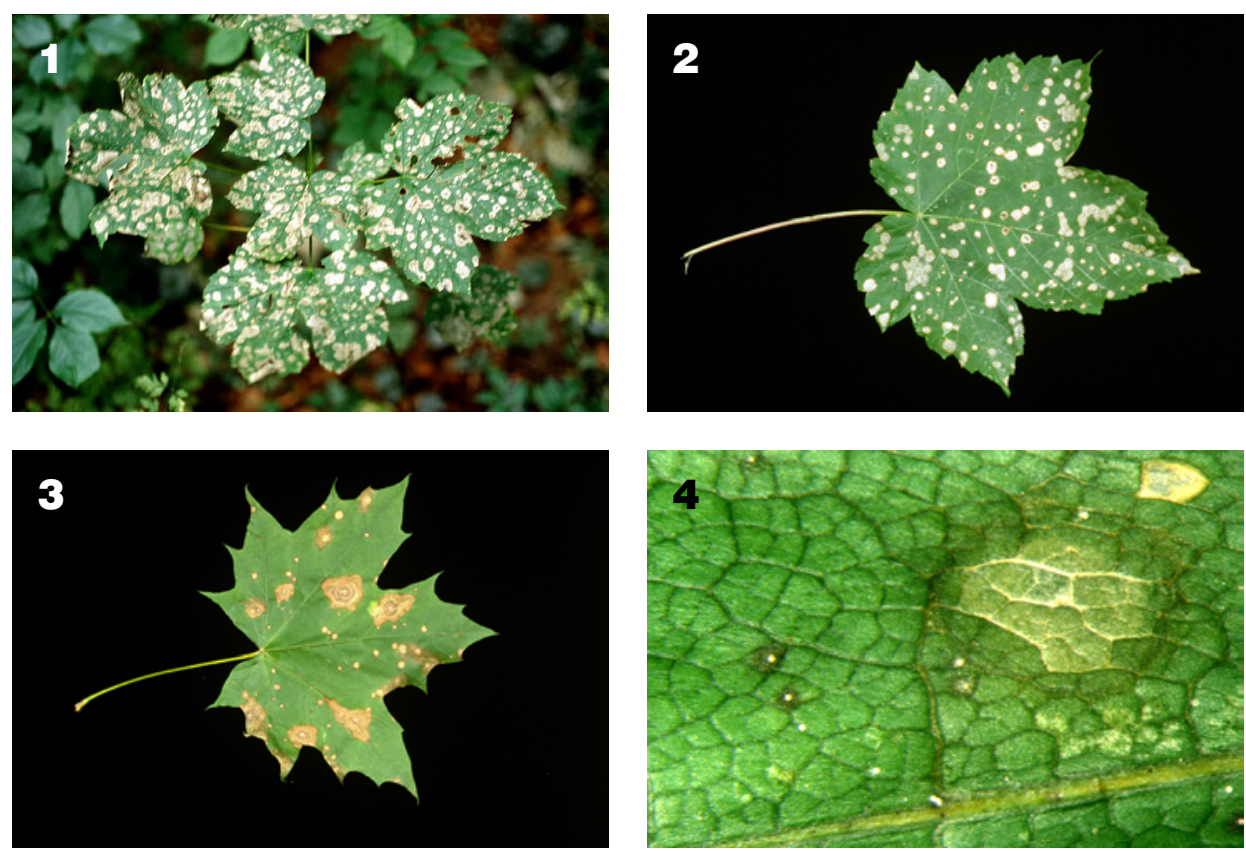

Figs 1-4. 1. A young sycamore (A. pseudoplatanus) with symptoms of infection by $C$. depraedans on all leaves in the crown; 2. A leaf of $A$. pseudoplatanus with numerous necrotic spots caused by $C$. depraedans; 3 . A leaf of $A$. platanoides with numerous necrotic spots caused by $C$. depraedans; 4. A leaf of $A$. platanoides with the local lesions of different size resulting from different infection times by $C$. depraedans. 

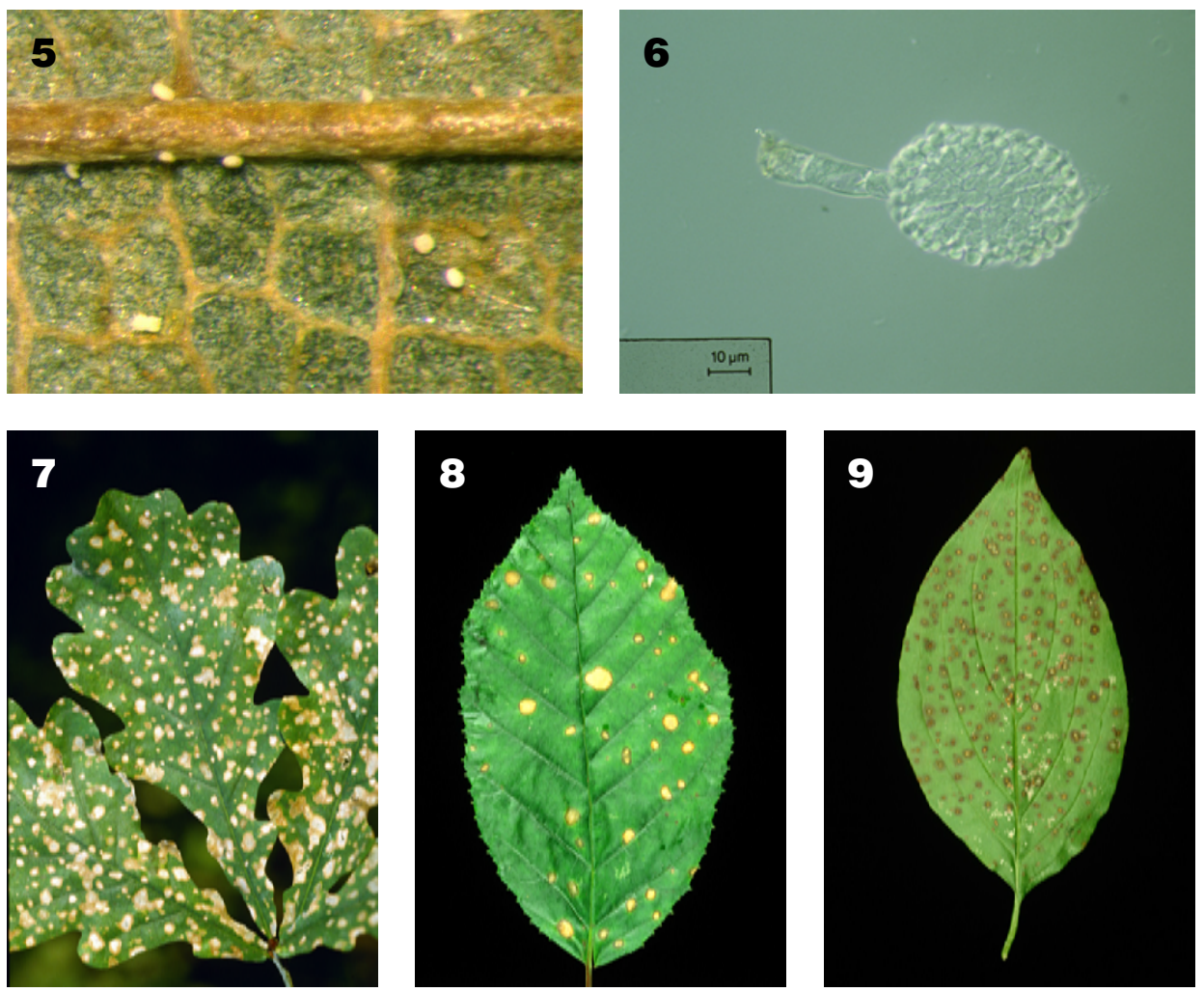

Figs 5-9. 5. Propagules of $C$. depraedans on the underside of a leaf lesion on A. platanoides; 6. Propagulas of $C$. depraedans (magnified); 7. Leaves of Quercus robur with symptoms of infection by $C$. depraedans; 8 . Leaf developed on sprout of Carpinus betulus with symptoms of infection by $C$. depraedans; 9. Leaf of Cornus sanguinea with symptoms of infection by C. depraedans. 